\title{
Statyba
}

\section{ANALYSIS OF EFFICIENCY OF SINGLE-FAMILY HOUSE LIFE CYCLE}

\section{N. Kvederytè}

To cite this article: N. Kvederytè (2000) ANALYSIS OF EFFICIENCY OF SINGLE-FAMILY

HOUSE LIFE CYCLE, Statyba, 6:6, 445-450, DOI: 10.1080/13921525.2000.10531629

To link to this article: https://doi.org/10.1080/13921525.2000.10531629

曲 Published online: 26 Jul 2012.

Submit your article to this journal ๘

III Article views: 69

7 Citing articles: 1 View citing articles 


\title{
ANALYSIS OF EFFICIENCY OF SINGLE-FAMILY HOUSE LIFE CYCLE
}

\author{
N. Kvederytè
}

Vilnius Gediminas Technical Universit!

\section{Introduction}

An efficient single-family house is a final purpose of life cycle. It determines the necessity to evaluate various decisions of life cycle of single-family houses, and possibilities to satisfy objectives and requirements of participants of that process. To design and achieve an efficient process of a single-family house life cycle it is necessary to take care of the building efficiency starting from the determination of needs and objectives and ending to usage of a building. In each stage of the life cycle of a building many interested parties are involved: clients, designers, contractors, manufacturers and suppliers of construction materials and products, users, public and municipal institutions, buildings supervisory and repair organisations, etc. While designing the life cycie of a building and making decisions, it is necessary to take into account the interests of these interested parties. Therefore the life cycle of a single-family house has to be designed and implemented taking into consideration its stages, objectives and opportunities of the interested parties after evaluating the environment of micro- and macro-level, simultaneously influencing the efficiency of a single-family house. A variety of factors describing efficiency of single-family houses poses a question: how to evaluate decisions of the life cycle of a building in many aspects:?

Many research works have been reported for solsing reles ant problems of a particular stage of a building life cycte tic brict. design. construction. maintenance) [1-3]. Must systems. such as QM-XPS |H]. the CABMaS research project developed under the heading of "Cooperative Research" [5]. and the tools proposed by G. Aouad [6]. Y. E. Kalay [7], G. Coetzee et al. [8], use information technology (IT) to support the different decisions of a building life cycle and managing their associated information.
C. M. Eastman et al. [9. 10] presented a survey of software programs, IT, expert and decision support systems used world-wide for solving problems related to brief, design, construction and maintenance processes. According to D. Veeramani et al. [11], the transition of the construction industry to the computer-integrated era requires the development and acceptance of collaboration technologies for all steps of a construction project from design, through construction process planning, as well as project execution and management. In this context, the growing popularity of the WWW and Internet-based technologies is creating new promising approaches to collaborative design, contractor selection, construction process planning and execution, and project coordination.

This paper proposes a model of complex analysis of a single-family house life cycle and the possibilities of its realization. Its purpose is to provide a structure for development of new capabilities and tools for a more efficient implementation of objectives and needs of the interested parties.

\section{Analysis and evaluation of efficiency of life cycle of a single-family house}

\subsection{Development of a model for a complex analysis of a single-family house life cycle}

In order to design and realize an efficient life cycle of a building. it is necessan Io take care of the huilding efficiency from the inception to the end of service life. The entire process must be planned and executed with consideration of its key stages. objectives and opportunities of interested parties involved in the process and the environment of micro- and macro level. For complex solving problems and increasing efficiency, a model of analysis of a building life cycle was developed (see Fig) [12, 13]: 
- Analysis of component parts of the building life cycle (stages, participants and the factors of environment influencing the building life cycle).

- Multivariant design of life cycle of a building.

- Multple criteria analysis of life cycle of a building.

- Development of rational micro- and macro-level environment.

- Selection of the efficient variant of life cycle of a building and realization of purposes of the interested parties involved.

The life cycle of a building can be divided into five closely interrelated stages, such as inception, design, construction, in-use and demolition. At the stage of inception the client and designers state major requirements and limitations regarding the building in question. A single-family house is being designed with an account of the client's needs as well as the possibilities of designers, constructors, suppliers, etc. At the design stage of building life cycle, multivariant design and multiple criteria analysis should be carried out taking into account the experience gained in realizing similar projects and seeking to harmonize the activities of the interested parties. The strategy and means of its realization related to building maintenance and facilities management should be defined. They should ensure that maintenance and facilities management problems

\begin{tabular}{|c|c|c|c|}
\hline \multirow{14}{*}{ 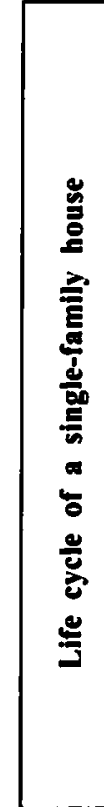 } & \multirow[b]{3}{*}{$=$} & \multirow{5}{*}{ Stages } & Inception \\
\hline & & & Design \\
\hline & & & Construction \\
\hline & \multirow{6}{*}{$<$} & & In-use \\
\hline & & & Demolition \\
\hline & & \multirow{7}{*}{$\begin{array}{l}\text { Interested } \\
\text { parties }\end{array}$} & Clients \\
\hline & & & Designers \\
\hline & & & Contractors \\
\hline & & & Manufacturers and suppliers of construction materials and products \\
\hline & \multirow{5}{*}{$r^{2}$} & & Users \\
\hline & & & Buildings maintenance and repair organisations \\
\hline & & & $\ldots$ \\
\hline & & \multirow{2}{*}{$\begin{array}{l}\text { Environment } \\
\text { factors }\end{array}$} & Micro-level environment \\
\hline & & & Macro-level environment \\
\hline \multicolumn{4}{|c|}{------1} \\
\hline \multicolumn{4}{|c|}{ Multivariant design of life cycle of a building } \\
\hline \multicolumn{4}{|c|}{7} \\
\hline \multicolumn{4}{|c|}{ Multiple critcria analysis of lile cycle of a building - Multiple criterial cvaluation of alternatives } \\
\hline \multicolumn{4}{|c|}{7} \\
\hline \multicolumn{4}{|c|}{ Selection of efliciemt variant of life cycle of a huilding $-\mid$ Selection of eflicient altemalives } \\
\hline \multicolumn{4}{|c|}{ 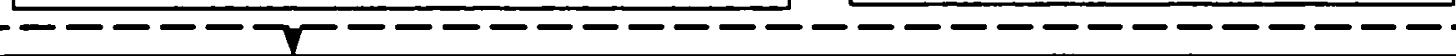 } \\
\hline \multirow{4}{*}{\multicolumn{2}{|c|}{ 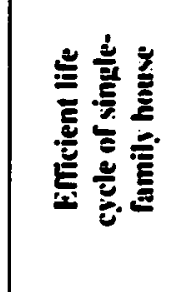 }} & \multicolumn{2}{|r|}{ Development of rattional micro- and macro-level envirumment } \\
\hline & & \multicolumn{2}{|c|}{ - Determination of rattional stages and their constiluent parts } \\
\hline & & & $::$ \\
\hline & & & $\begin{array}{l}\text { Eflicient realization of purposes of interested partics. } \\
\text { taking into consideration their opportunities }\end{array}$ \\
\hline
\end{tabular}

Fig 1. A model for a complex analysis of a single-family house life cycle 
are continually dealt with, starting from the inception stage.

A building life cycle may have a lot of alternative versions. These versions are based on alternative inception, design, construction, in-use and demolition processes and their constituent parts. The above solutions and processes may be further considered in detail. For instance, varying its three-dimensional planning, as well as structural and engineering solutions alternative single-family house variants may be developed. Thus, dozens of thousands of alternative versions can be obtained.

Since the rationality of the project aspects often depends on a particular participant, only a complex design of a single-family house life cycle involving close collaboration of major interested parties can lead to good results.

The efficiency of a building life cycle depends on a number of variables, at micro- and macro-levels. The efficiency also depends on the influence of many complex macro-level factors (the government policy, legal and institutional infrastructure, physical infrastructure, financial sector, environment issues, unemployment, interest rate, inflation, innovations, and exchange rate). The efficiency level will, therefore, vary depending on the aggregate effect of these macro-level factors.

The method of multiple criteria multivariant design [14] is applied for making variants of the singlefamily house life cycle. From the standpoint of longterm prospects, the multivariant design and multiple criteria evaluation of a building life cycle allows the interested parties to make efficient decisions on the ground of quantitative and qualitative variants analysis. Methods of multiple criteria analysis (method of complex determination of the significances of the criteria. method of multiple criteria complex proportional evaluation of the projects. method of defining the utility degree) $|14|$ are applied for complex analysis as well as evaluation of decisions.

Hence. the life cycle efficiency depends to a great extent not only on the selected processc:s and solutions. the interest level of the parties involved in the project. expressed as the effectiveness of their participation in the process. but also on the micro- and macro-level factors. As Fig shows, the object of investigation is rather complicated; it involves not only a building life cycle and its stages but also the interested parties and micro- and macro-environment factors having impact on the former. For selecting a rational project a new building life cycle complex analysis model was developed. Using this model, the interested parties are able to design alternative variants of a single-family house life cycle (various decisions), to evaluate them and determine the most efficient point: to find an efficient decision for the existing situation. A variety of decisions allows to evaluate more exactly the life cycle in economic. qualitative. legal. technological and other aspects, to agree the interests of the interested parties.

\subsection{Realization of a model for a complex analysis of a single-family house life cycle}

A practical realization of a model for a complex analysis of life cycle of single-family houses was being developed step by step as follows:

- A comprehensive quantitative and conceptual description of the life cycle of a building, its key stages, interested parties and environment by a set of criteria.

- Development of a complex database based on quantitative and conceptual description of the building life cycle.

- Development of a decision support system of the building life cycle, which would allow to make a complex analysis of such process, to perform a multiple criteria multivariant design and evaluation thereof.

In order to perform a complete study of the building life cycle. a complex evaluation of its economic, technical. qualitative (ie architectural, aesthetic. comfortability). technological, social. legislative, infrastructural and other aspects is needed. The diversity of aspects being assessed should result in the diversity of ways of presenting data needed for decision-making. Therefore. the necessary data may be presented in numerical. extual. graphical (schemes. graphs. charts). formula. sideotape and other forms.

In order to assess fully the influence of the constituent parts of a building life cycle affecting the total efficiency of a project. it is necessary to express them through systems of criteria. The altematives of life cycle of the single-family houses (decisions thereof) are evaluated on the basis of the following criteria groups: 
price of a land plot, engineering networks - electric power, water supply, sewerage, etc - telephone, recreational opportunities, roads and access possibilities. dwelling territory. neighbours, district prestige. opportunities of district development, configuration of a land plot, properties of ground, air pollution. etc. Some complex systems of qualitative and quantitative criteria characterising the life cycle are discussed in the author's research [15]. The suggested criteria system allows to evaluate how economic, architectural, technical, technological, comfort and other decisions meet the needs and opportunities of the clients, designers, contractors, users and other participants of this process.

Conceptual and quantitative description of the component parts of a building life cycle provides the information on various aspects of a cycle (ie economical, technical, technological, infrastructural, qualitative, etc). The conceptual description presents textual, graphical, visual information about the projects and the criteria used for their definition, as well as giving the reason for the choice of a particular system of criteria, their values and significances. This part also includes information about the possible ways of multivariant design. The quantitative information is based on the criteria systems and subsystems, units of measurement, values and initial significances as well as the data on the alternative project development.

The life cycle of a building, influencing factors and the interested parties are described in qualitative and conceptual forms. An analysis of component parts of the single-family house life cycle (stages, participants and the environment factors influencing a building life cycle), conceptual and quantitative description of them may be found in [12, 15].

Conceptual and quantitative description of a building life cycle and its stages is used as a basis for developing complex databases containing overall information and allowing to carry out its multivariant design and multiple eriteria analysis. Since the efficienc! of any proyiect constituent part depends on a particular pan of its execution only a complex design of a building life cycle involving close cooperation of all interested parties can yield good results.

Alternative life cycle versions include different cost of a plot and a building, maintenance costs as well as architectural, aesthetic, comfortability characteristics, infrastructure and environment pollution. The interested parties often have their own preferential rating of these criteria. giving also different values to qualitative characteristics. Besides, designing a building life cycle allows the development of plenty of alternative versions of its particular stages. This causes a lot of problems in determining the most efficient project. To overcome these difficulties some complex databases were developed [15]. They contain a complex description of the alternative versions available in conceptual and quantitative forms. These data taken together can describe the object to be considered in detail. The application of complex databases described allows to better satisfy the needs of the parties involved as well as helping to choose an efficient life cycle. The problems solved using a complex database described may be found in some publications of the author $[12,13,15]$.

Interacting with the databases the user can get more detailed or integral information on the object considered. Given this opportunity and using the data from complex databases as well as being provided with a decision support system, the user can find an efficient project variant in a comparatively short time. In this way, a project best satisfying the client's needs may be found saving the time for the client and designers.

In order to design a number of alternative life cycle versions as well as to determine the utility degree of the alternatives obtained and to set the priorities, methods of multiple criteria multivariant design and multiple criteria analysis $[14,16]$ were applied.

It is quite obvious that to develop and analyse thousands of alternative variants based on dozens of criteria having each specific values and significances would be hardly possible without the IT tools. Only development of decision suppon systems could help solve this problem. Therefore. to achieve the above-menlioned aims an original decision support system “P(iP 1.0\%. its components lic database. database management system. modelbasc. modelbase management system and user's intertace) were developed [15]. The system allows to evaluate the single-family houses life cycle in complex. ie to take into account different stages of a cycle. interested parties involved in the process and factors of environment. 
3. A decision support system of the single-family houses life cycle

Seeking strategic. economic. technical, social, qualitative and other goals. it is necessary to base on quantitative and qualitative evaluation criteria describing objectives and opportunities, alternative decisions of interested parties, and the existing situation of environment. Seeking to define ground and reach these objectives it is required to apply the methods of multiple criteria design and analysis. Methods of multiple criteria multivariant design and analysis $[14,16]$ being applied in the developed decision support system. assist to establish in quantitative and qualitative terms an efficient life cycle of single-family houses (decisions thereof) as well as to determine the level of projects utility.

The decision support system for solving problems related to construction activities and the life cycle of a building can be considered a modern and advanced tool. This tool helps the participants of the building life cycle to seek successfully their objectives. While applying the methods of multiple criteria analysis in decision support system it is possible to settle a problem of optimisation of the intended objectives and sources required for their implementation.

Using the information gathered in decision support system database and following the models of model base, the interested parties (including building owners and users, architects, engineers, manufacturers of building materials, contractors, state and its institutions, local governments, etc) of the process of the single-family houses life cycle are able to make efficient decisions. The use of multiple criteria analysis methods in the decision support system makes conditions for implementing objectives of interested parties and satisfying their needs. The solution of sample problems of increasing the efficiency of a building life cycle or its particular stages with the use of the multiple criteria decision support system suggested may he lound in the author's rescarch [1.5].

\section{Conclusions and suggestions}

1. There is an evaluation model of analysis of the life cycle of the single-family houses developed. The analysis showed that the efficiency of a building life cycle depends on adjustment of stage decisions and interests of parties involved in the process, implementation of objectives and environment influencing the project. Implementation of the developed model of complex analysis would allow the interested parties to meet more efficiently their needs and objectives, to evaluate in detail all expenses relative to implementation of the project and the results obtained.

2. Conceptual and quantitative description of the single-family houses life cycle and different alternatives of its decisions is proposed, which allows to evaluate in detail the life cycle of a building. Following the conceptual and quantitative information. which describes the life cycle of a building, the interested parties (taking into account their priorities and the existing situation) are able to rationalise the decisions made.

3. The proposed methodology allows to evaluate the single-family house life cycle as a whole, ie to take into account different stages of a building life cycle, the interested parties and factors of environment.

4. Methods of multiple criteria multivariant design and analysis being applied in the developed decision support system may be useful for establishing in quantitative and qualitative terms the efficient life cycle of the single-family houses (decisions thereof) as well as to determine the level of utility of projects. The application of the methods of multiple criteria analysis in the decision support system predetermines conditions for implementing objectives of the interested parties (clients, designers, contractors, user, etc) and guarantee a satisfaction of their needs.

\section{References}

I. P. S. Barrett. J. Hudson. C. Stanley. Good practice in bricfing: the limits of rationality / Automation in Construction. $\&$ (6). 1999. p. 633642.

2. A. S. Hanna. W. B. Lotfallah $\wedge$ fuzzy logic approach W sclectlon of cranc: Automation in Construction. $\&(5)$ 1404. n. 597 (1018.

: Wi-d. Yu. M. J. Skibnicuski. A neuro-turn computationnal approach to construability know ledgec acquisilson for consirucioon tcithnology coaluation Automation in Convinution. $\times$ (5). 1949, p. 534553.

4. D. Rethelj. I. Psiunder. Product medel based yuality management sysiem /: The Life-Cycle of Consinuction IT Innovations Technology Transfer from Rexearch to practice. Procecdings of the CIB Working Commission W78 Information Technology in Construction Conference in Stockholm June 3-5, 1998. Eds. B.-C. Bjork. A. Jagbeck. Stockholm: Royal Institute of Technology, 1998. p. $367-372$. 
5. A. Dupagne. P. Mathus. CABMAS (Computer aided building management system): development of an integrated computerised platform for the management of information flows adapted to small and medium size building companies / The Life-Cycle of Construction IT Innovations - Technology Transfer from Research to practice. Proceedings of the CIB Working Commission W78 Information Technology in Construction Conference in Stockholm June 3-5. 1998. Eds. B.-C. Bjork, A. Jagbeck. Stockholm: Royal Institute of Technology. 1998, p. 179-190.

6. G. Aouad. Integration: from a modelling dream into an implementation reality // International Workshop on Information Support for Building Economics. Proccedings of the International Workshop held at the University of Salford and Armathwaite Hall. United Kingdom, I"'-t"th September 1997. Ed. by L. Ruddock CIB Publication Number 210. University of Salford, 1997, p. 7-29.

7. Y. E. Kalay. Performance-based design // Automation in Construction. 8 (4), 1999, p. 395-409.

8. G. Coetzee. N. Boshoff. The use of electronic commerce in the materials procurement in SA construction industry // The Life-Cycle of Construction IT Innovations - Technology Transfer from Research to practice. Proceedings of the CIB Working Commission W78 Information Technology in Construction Conference in Stockholm June 3-5, 1998. Eds. B.-C. Bjork, A. Jagbeck. Stockholm: Royal Institute of Technology, 1998, p. 141-150.

9. D. Veeramani, H. P. Tserng. J. S. Russell. Computerintegrated collaborative design and operation in the construction industry // Automation in Construction, 7 (6), 1998. p. $485-492$.

10. C. M. Eastman, A. Siabiris. A generic building product model incorporating building type information /" Automation in Construction, 3 (4), 1995, p. 189-304.

11. C. M. Eastman. Life cycle requirements for building product models // Management of Information Technology for Construction. Proceedings of the First International Conference on the Management of Information Technology for Construction. Eds. K. Mathur, M. Betts, K. Tham. Singapore: World Scientific \& Global Publication Services, 1993, p. 369-389.

12. N. Kvederytė. Vienbučiu gyvenamuju namu efektyvumas derinant ju gyvavimo proceso dalyviu interesus: Daktaro disertacija: technologijos mokslai. statybos inžinerija. Vilnius. 2000. $159 \mathrm{p}$.

13. N. Kvederytc. E. K. Zavadskas. $\wedge$. Kaklauskas. Vienbuciu gyvenamujy namy gyvavimo proceso daugiakritcrinc analize , Statyba (Civil Engincering). V1 1.. Nr. 3. Vilnius: Technikia. 2000. p. 179192.

14. N. Kiederyti. E. K. Zavadskas. A. Kaklauskias. Pastato gyarimo proceso daugiakriterinis altematyvusis propick-

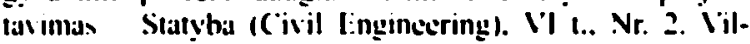
nus. Tichnikia. 2(K0), p. 12X 142.

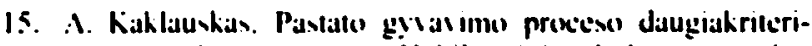
nıu prendimy sislema: Habilıtacinio darbo santrauka. technologijon mokslai. stalybos inžinerija. Vilnius: Technikid. $1999.90 \mathrm{p}$.

16. E. K. Zavadskas. L. Simanauskas. A. Kaklauskas. Sprendimu paramos sistemos statyboje. Vilnius: Technika. 1998. $235 \mathrm{p}$.

Iteikta 20001206

\section{VIENBUČIŲ GYVENAMŲJU NAMŲ GYVAVIMO PROCESO EFEKTYVUMO ANALIZÉ}

\author{
N. Kvederytè
}

Santrauka

Norint suprojektuoti ir igyvendinti efektyvu vienbučio gyvenamojo namo gyvavimo procesą. būtina jo racionalumu rūpintis nuo poreikiy ir tikslu nustatymo iki pastato naudojimo pabaigos. Kiekvienu pastato gyvavimo proceso etapu dalyvauja ivairios suinteresuotos grupès: użsakovai. projektuotojai. rangovai. statybiniu medžiagu bei gaminiu gamintojai ir tiekçjai. naudotojai. pastatu prieżiūros ir remonto organizacijos ir kt. Projektuojant pastato gyvavimo procesa ir priimant sprendimus. reikia atsižvelgti i šiu suinteresuoty grupių interesus. Plètojant kompleksinị pożiūri, vienbučio gyvenamojo namo gyvavimo proceso efektyvumas priklauso nuo kitu sistemos dalių konkrečiu momentu. Todèl vienbučio gyvenamojo namo gyvavimo procesas turi būti projektuojamas ir igyvendinamas, atsižvelgiant $i$ jo pagrindinius etapus, dalyvaujančiu suinteresuoty grupiu tikslus ir galimybes. ivertinant išorinę mikro- ir makrolygmens aplinka, t. y. i visus veiksnius, turincius jtakos vienbučio gyvenamojo namo gyvavimo proceso efektyvumui.

Straipsnyje pateikiamas vienbuciu gyvenamuju namu gyvavimo proceso efektyvumo kompleksinei analizei sukurtas teorinis modelis, kuriame ivairūs veiksniai ir aplinkybès aprašomi kriteriju rinkiniu. Remdamosi šiuo modeliu suinteresuotos grupès, rengiančios ir realizuojančios projekta, gali projektuoti alternatyvius vienbučio gyvenamojo namo gyvavimo proceso (ivairiu sprendimu) variantus, juos ivertinti ir nustatyti racionaliausią: esamai situacijai rasti efektyvı sprendimą. Sprendimu variantiškumas padeda realiau ir racionaliau ivertinti pastato gyvavimo procesą ekonominiais, kokybiniais (architektūriniais, tūriniais, planiniais, estetiniais). teisiniais, techniniais, technologiniais ir kitais aspektais, suderinti suinteresuoty grupiy interesus. Pagal pateikta modeli sukurta ir sprendimu paramos sistema. Si sistema pastato gyvavimo proceso dalyviams padeda sèkmingai siekti savo tikslu. didinti pastato gyvavimo proceso efektyvumą. Sprendimu paramos sistemoje taikomi pastato gyvavimo proceso daugiakriterinio altematyviojo projektarimo ir daugiakriterinio ivertinimo metodai leidżia išspressti sickiamy tiksly ir șiems tikslams igyvendinti reikalingụ ištcklliu optimizacijos uždavini: išanalizavus galimus vienbuèo g!venamojo namo gyvavimo proceso variantus nustatomas racionaliausias sio proceso dalyviy (suinteresuoty grupiy) sickiamu! tikslu ir turimu galimybiy derings.

Derija KVE.DF.RITË. Dockor. Dept of (onvruction Techno-

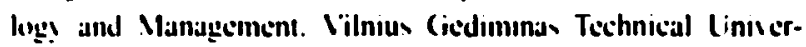
sț. Sauletckio al. II. LT-2040 Vilnıs, Lithuania. E-mail: nerịa.kicederyteu st.vitu.lt

A graduate of Vilnius Gediminas Technical Universiry. civil engineer (1993). MSc (1995). PhD (civil engineering. 2000). Rescarch interests: building life cyclc. multiple criteria decision-making. decision support systems. 